University of South Carolina

Scholar Commons

1973

\title{
Electrochemical Reduction of Molybdenum(VI) Compounds in Molten Lithium Chloride-Potassium Chloride Eutectic
}

Branko N. Popov

University of South Carolina - Columbia, popov@engr.sc.edu

H. A. Laitinen

University of Illinois at Urbana

Follow this and additional works at: https://scholarcommons.sc.edu/eche_facpub

Part of the Chemical Engineering Commons

\section{Publication Info}

Journal of the Electrochemical Society, 1973, pages 1346-1350.

(c) The Electrochemical Society, Inc. 1973. All rights reserved. Except as provided under U.S. copyright law, this work may not be reproduced, resold, distributed, or modified without the express permission of The Electrochemical Society (ECS). The archival version of this work was published in the Journal of the Electrochemical Society.

http://www.electrochem.org/

DOI: $10.1149 / 1.2403259$

http://dx.doi.org/10.1149/1.2403259

This Article is brought to you by the Chemical Engineering, Department of at Scholar Commons. It has been accepted for inclusion in Faculty Publications by an authorized administrator of Scholar Commons. For more information, please contact digres@mailbox.sc.edu. 
$T$ absolute temperature $\left({ }^{\circ} \mathrm{K}\right)$

$U_{i} \quad$ eigenfunctions in series for $\Phi^{\mathrm{t}}$

$U_{i, 0} \quad$ value of $U_{i}$ at the electrode surface

$V$ electrode potential (V)

$V$ ss steady-state part of the electrode potential (V)

$V^{t}$ transient part of the electrode potential (V)

$z \quad$ distance from plane of disk $(\mathrm{cm})$

$\alpha_{\mathrm{a}}, \alpha_{\mathrm{c}}$ parameters in the kinetic coefficient

$\delta \quad$ Nernst diffusion layer thickness $(\mathrm{cm})$

$\delta_{m, n} \quad$ Kronecker delta

$\eta \quad$ rotational elliptic coordinate

$\eta_{\mathbf{s}} \quad$ surface overpotential (V)

$\kappa \quad$ conductivity of the solution $\left(\mathrm{ohm}^{-1}-\mathrm{cm}^{-1}\right)$

$\Lambda_{i}$ dimensionless eigenvalue

$\Lambda_{\mathrm{D}} \quad$ eigenvalue characteristic of diffusion

$\Phi$ potential in the solution (V)

$\Phi_{0} \quad$ value of $\Phi$ at the electrode surface (V)

$\Phi^{\text {ss }} \quad$ steady-state part of potential in the solution (V)

$\Phi^{\mathrm{t}} \quad$ transient part of potential in the solution (V)

$\Phi_{0}{ }^{p} \quad$ potential in the solution adjacent to the disk corresponding to the primary current distribution (V)

$\xi \quad$ rotational elliptic coordinate

$\tau_{i}$ time constants for decay ( $\left.\mathrm{sec}\right)$

$\theta$ dimensionless time for the charging period

$\theta^{*} \quad$ dimensionless time for the decay period

$\theta_{\mathrm{ch}}$ dimensionless total period of charging

$v_{i} \quad$ constants in the series for $V^{t}$ (normalized to unity)

$\boldsymbol{\Omega}$ angular frequency of rotation (radians/sec)

\section{REFERENCES}

1. S. Glasstone, J. Chem. Soc., 123, 2926 (1923).

2. A. Hickling, Trans. Faraday Soc., 33, 1540 (1937).

3. S. Schuldinger and R. E. White, This Journal, 97, 433 (1950).
4. J. D. E. McIntyre and W. F. Peck, Jr., ibid., 117, 747 (1970).

5. J. Newman, ibid., 113, 501 (1966).

6. J. Newman, ibid., 113, 1235 (1966).

7. J. Newman, ibid., 114, 239 (1967)

8. J. Newman, ibid., 117, 507 (1970).

9. L. Nanis and W. Kesselman, ibid., 118, 454 (1971); and ibid., 118, 1967 (1971).

10. J. Newman, ibid., 118, 1966 (1971).

11. W. Tiedemann, J. Newman, and D. N. Bennion, ibid., 120, 256 (1973).

12. B. Miller and M. I. Bellavance, ibid., 120, 42 (1973).

13. J. Newman, Intern. J. Heat Mass Transfer, 10, 983 (1967).

14. W. R. Parrish and J. Newman, This Journal, 116, 169 (1969).

15. W. R. Parish and J. Newman, ibid., 117, 43 (1970).

16. J. Newman, J. Phys. Chem., 73, 1843 (1969).

17. J. Newman, This Journal, 117, 198 (1970).

18. D. C. Grahame, Chem. Rev., 41, 441 (1947).

19. E. Levart and D. Schuhmann, J. Electroanal. Chem., 24, 41 (1970).

20. A. M. Johnson and J. Newman, This Journal, 118, 510 (1971).

21. J. Newman, "Electrochemical Systems," p. 58, Prentice-Hall, Inc, Englewood Cliffs, N. J. (1973).

22. E. Mattsson and J. O'M. Bockris, Trans. Faraday Soc. 55, 1586 (1959).

23. D.-T. Chin, This Journal, 118, 1434 (1971).

24. R. Parsons, Advan. Electrochem. Electrochem. Eng., 1, 1 (1961)

25. K. Nisancioğlu and J. Newman, This Journal, 120, $1356(1973)$.

26. J. R. Selman, Ph.D. Thesis (UCRL-20557), University of California, Berkeley, June, 1971.

27. L. Nanis and I. Klein, This Journal, 119, 1683 (1972).

\title{
Electrochemical Reduction of Molybdenum(VI) Compounds in Molten Lithium Chloride-Potassium Chloride Eutectic
}

\author{
B. N. Popor \\ Faculty of Technology and Metallurgy, University Kiril and Metodij, Skopje, 91000, Yugoslavia \\ and H. A. Laitinen * \\ Roger Adams Laboratory, School of Chemical Sciences, University of Illinois, Urbana, Illinois 61801
}

\begin{abstract}
Molybdenum(VI) oxide reacts with molten $\mathrm{LiCl}-\mathrm{KCl}$ eutectic at $450^{\circ}$ to form $\mathrm{MoO}_{2} \mathrm{Cl}_{2}$, which probably is present as an anion $\mathrm{MoO}_{2} \mathrm{Cl}_{4}=$, and pyromolybdate, $\mathrm{Mo}_{2} \mathrm{O}_{7}=$. Both of these species are electrochemically reduced to $\mathrm{MoO}_{2}$, which can be reoxidized to $\mathrm{MoO}_{2} \mathrm{Cl}_{2}$ by current reversal. A second reduction step, observed whether $\mathrm{MoO}_{3}$ or $\mathrm{Mo}_{2} \mathrm{O}_{7}{ }^{2-}$ is added to the melt, can be attributed to the reduction of $\mathrm{MoO}_{4}=$, formed as a secondary reaction product in the first step. The reduction of molybdate proceeds in two steps, the first at $-0.85 \mathrm{~V}$ and the second at $-1.75 \mathrm{~V}$ vs. the $1 \mathrm{M} \mathrm{Pt}$ (II) $/ \mathrm{Pt}$ reference electrode. The first step shows an abnormally short transition time, attributable to a slow equilibrium. The second step corresponds to a diffusion-controlled reduction with $n=0.5$, yielding a product of the empirical formula $\mathrm{Li}_{5} \mathrm{Mo}_{2} \mathrm{O}_{8}$.
\end{abstract}

The literature contains very little fundamental information on the behavior of molybdenum compounds in molten systems. Stavenhagen and Engels (1) described a sodium molybdenum bronze in the form of a dark bluish-grayish powder formed by electrolytic reduction of fused sodium molybdate. Cannery (2) reported the preparation of lithium, sodium, and potassium molybdenum bronzes using the same method. However, the next year Burgers and van Liempt (3) showed that the bronzes mentioned by Cannery were

* Electrochemical Society Active Member.

Key words: molybdenum, molybdenum(VI) oxide, molybdenum oxychloride, lithium pyromolybdate, lithium molybdate, molten salts, electrochemistry. mixtures consisting of molybdenum(IV) oxide and molybdenum blue. According to Magneli, only molybdenum oxides were obtained by Hagg in similar experiments $(4,5)$. Wold, Kunmann, Arnot, and Ferretti (6) prepared pure $\mathrm{MoO}_{2}$ crystals by electrolytic reduction of $\mathrm{MoO}_{3}-\mathrm{Na}_{2} \mathrm{MoO}_{4}$ mixtures at $675^{\circ} \mathrm{C}$. In addition, both sodium molybdenum bronze and potassium molybdenum bronze crystals were grown from molybdenum (IV) oxide-alkali molybdate melts under carefully controlled conditions. Senderoff and Brenner ( 7 , 8) have investigated the reduction of molybdate dissolved in molten alkali halides. They found that the bulk of the reaction product was dispersed throughout 
the melt as a black, water insoluble powder containing about $77 \%$ molydenum, corresponding to $\mathrm{MOO}_{2}(75 \%$ Mo).

The present investigation was undertaken in order to study the reduction of molybdenum(VI) compounds and to characterize any reduction products observed. It was also considered possible that some aspects of molybdenum chemistry and interactions between molybdenum(VI) compounds and chloride melt could be deduced.

\section{Experimental}

Apparatus.-The instrumentation and equipment used in this study have been previously described (911).

Electrodes.-Platinum microelectrodes for voltammetry were prepared from $26 \mathrm{~B}$ and $\mathrm{S}$ gauge platinum wire as described earlier (10). Indicator electrodes for chronopotentiometric measurements were made by sealing 26 gauge platinum wire into Pyrex glass and then spot welding a piece of $0.5 \mathrm{~cm}^{2}$ platinum foil to the end of the wire extending from the platinum glass seal. The cathodes used for the preparation of the electrode deposits were constructed from 52-mesh platinum gauze. The counterelectrode was a $1 / 8-i n$. diameter graphite rod. All potentials are referred to the $1 \mathrm{M} \mathrm{Pt}$ (II) $/ \mathrm{Pt}$ reference electrode. Details on the generation and use of this reference electrode in LiCl-KCl have been described previously $(11,12)$.

Chemicals.-All chemicals used in this study were reagent grade. Those chemicals containing water of hydration were vacuum dried at $110^{\circ} \mathrm{C}$ before being added to the melt.

The LiCl-KCl eutectic was obtained from Anderson Physics Laboratories, Inc., Urbana, Illinois. The method of purification has been described (11). All experiments in the melt were carried out at $450^{\circ} \mathrm{C}$ unless otherwise noted.

Solid chemicals were added to the melt by means of a small glass spoon. A blanket of argon was kept over the melt at all times to exclude oxygen and water vapor. The purification train used in purifying the argon has been described (13).

Techniques for preparation and analysis of electrode deposits.-Before their insertion in the melt solution, the gauze electrodes were cleaned in boiling, concentrated $\mathrm{HNO}_{3}$, rinsed with distilled water, and dried at $130^{\circ} \mathrm{C}$ for $20 \mathrm{hr}$. After the material had been deposited on the electrode, the electrode was allowed to cool, washed with deionized water, and dried at $120^{\circ} \mathrm{C}$. The deposits were then dissolved in $5 \mathrm{ml}$ of concentrated nitric acid by heating on a hot plate. The molybdenum content of the deposit was determined by addition of an excess of $\mathrm{Pb}^{2+}$ which was back-titrated with EDTA using xylenol orange as the indicator. The total molybdenum was also obtained by amperometric titration with lead, a procedure developed by Aylward (14). The amount of reduced molybdenum in the sample was determined by the method developed by Bourret (15). Lithium was quantitatively determined by flame photometry. Chloride was determined by the Volhard method.

\section{Results and Discussion}

$\mathrm{MoO}_{3}-\mathrm{LiCl}-\mathrm{KCl}$ system.-Preliminary steady-state voltammetric experiments (Fig. 1) showed that $\mathrm{MoO}_{3}$ exhibits two reduction waves in $\mathrm{LiCl}-\mathrm{KCl}$ at $450^{\circ}$. The half-wave potentials are approximately -0.3 and $-1.75 \mathrm{~V}$. The voltammetric curves were not highly reproducible because of the formation of an insoluble product which rapidly increases the surface area of the electrode. Upon prolonged electrolysis at the limiting plateau, a brown-violet film formed on the electrode, and the current increased with time. Chronopotentiometric experiments with proper choice of concentration and current density circumvented the difficulty due to film formation. Two transitions, at -0.35 and $-1.75 \mathrm{~V}$, respectively, were observed, in agreement with the voltammetric observations. The Sand equation was checked for the first reduction step

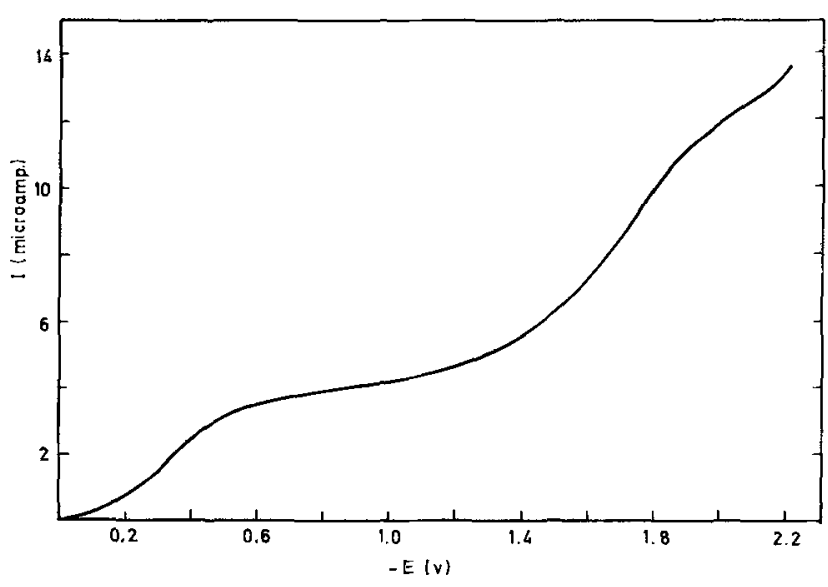

Fig. 1. Current-voltage curve for the reduction of $\mathrm{MoO}_{3}$. Electrode area $=2.2 \cdot 10^{-3} \mathrm{~cm}^{2} ; \mathrm{MoO}_{3}=3.63 \cdot 10^{-3} \mathrm{M}$.

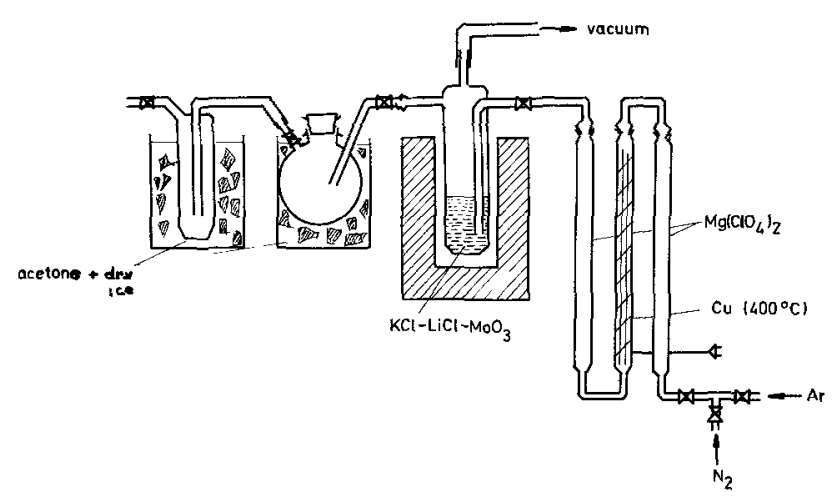

Fig. 2. Apparatus used to study acid-base reaction of $\mathrm{MOO}_{3}$ and chloride melt.

using four to six current densities at three different $\mathrm{MoO}_{3}$ concentrations (Table I). Constancy of the quantity $I \tau^{1 / 2} / C$ indicated diffusion-controlled reaction. However, it was observed during the measurements that a volatile product was slowly evaporating from the melt. Therefore, owing to the uncertain concentration it was not possible to calculate a valid diffusion coefficient from the data.

To establish the nature of the volatile product, the apparatus shown in Fig. 2 was used. Previously dried $\mathrm{MOO}_{3}$ was added to the melt, air was excluded, and the volatile product was displaced by inert gas into a weighed trap cooled with acetone and dry ice. The product was yellow in color, very volatile, and soluble in water. Analysis for $\mathrm{Mo}$ and $\mathrm{Cl}^{-}$by the methods described above showed that the sample weight could be completely accounted for in terms of the compound $\mathrm{MoO}_{2} \mathrm{Cl}_{2}$. To determine the product formed from the

Table 1. Chronopotentiometric data for the first reduction step of $\mathrm{MOO}_{3}$

\begin{tabular}{|c|c|c|c|}
\hline$\underset{(\mathrm{M})}{\mathrm{CMOO}_{3}}$ & $\underset{(\mathbf{m A})}{I}$ & $\begin{array}{c}I \tau^{1 / 2} \\
\left(\mathrm{~A}-\sec ^{1 / 2}\right)\end{array}$ & $\begin{array}{c}\mathrm{I} \mathrm{T}^{1 / 2} / \mathrm{C} \\
\left(\mathrm{A}-\mathrm{sec}^{1 / 2}\right. \\
\left.\mathrm{cm}^{3} \mathrm{~mol}^{-1}\right)\end{array}$ \\
\hline $3.63 \cdot 10^{-8}$ & $\begin{array}{l}1.540 \\
1.050 \\
0.550 \\
0.680 \\
0.596 \\
0.630\end{array}$ & $\begin{array}{r}0.784 \cdot 10^{-3} \\
0.715 \cdot 10^{-3} \\
0.671 \cdot 10^{-3} \\
0.664 \cdot 10^{-3} \\
0.660 \cdot 10^{-3} \\
0.680 \cdot 10^{-3} \\
\text { Avg } 0.679 \cdot 10^{-3}\end{array}$ & $\begin{array}{r}210 \\
197 \\
185 \\
183 \\
183 \\
187 \\
\text { Avg } 187\end{array}$ \\
\hline $9.84 \cdot 10^{-s}$ & $\begin{array}{l}2.500 \\
2.000 \\
1.670 \\
1.430\end{array}$ & $\begin{array}{r}1.802 \cdot 10^{-3} \\
1.780 \cdot 10^{-3} \\
1.734 \cdot 10^{-3} \\
1.770 \cdot 10^{-3} \\
\text { Avg } 1.770 \cdot 10^{-3}\end{array}$ & $\begin{array}{r}183 \\
181 \\
176 \\
181 \\
\text { Avg } 181\end{array}$ \\
\hline $2.3 \cdot 10^{-2}$ & $\begin{array}{r}10.000 \\
6.670 \\
\mathbf{5 . 5 5 0} \\
\mathbf{4 . 5 4 0}\end{array}$ & $\begin{array}{r}4.250 \cdot 10^{-3} \\
4.200 \cdot 10^{-3} \\
4.350 \cdot 10^{-3} \\
4.140 \cdot 10^{-3} \\
\text { Avg } 4.230 \cdot 10^{-3}\end{array}$ & $\begin{array}{r}185 \\
183 \\
189 \\
180 \\
\text { Avg } 184\end{array}$ \\
\hline
\end{tabular}


reaction of the oxide ion, the melt was extracted from the product with ethanol and acetone to yield $\mathrm{Li}_{2} \mathrm{MO}_{2} \mathrm{O}_{7}$, which accounted completely for the sample weight. Accordingly the reaction between $\mathrm{MoO}_{3}$ and the melt can be written

$$
3 \mathrm{MoO}_{3}+2 \mathrm{Cl}-\rightarrow \mathrm{MoO}_{2} \mathrm{Cl}_{2}+\mathrm{Mo}_{2} \mathrm{O}_{7}=
$$

A phase diagram study of $\mathrm{MoO}_{3}$ and $\mathrm{Li}_{2} \mathrm{MoO}_{4}$ was carried out to verify further the existence of $\mathrm{Li}_{2} \mathrm{Mo}_{2} \mathrm{O}_{7}$. Phase transition temperatures were determined for eight samples ranging in composition from 42 to 55 $\mathrm{m} / \mathrm{o}$ (mole per cent) $\mathrm{MoO}_{3}$. The experiments were done by the visual polythermal method in which the temperature of the first crystals was measured by a Pt-Rh thermocouple. From Table II it is evident that a local maximum exists for the molar ratio $\mathrm{MoO}_{3} /$ $\mathrm{Li}_{2} \mathrm{MoO}_{4}=1$, implying the formation of a solid compound $\mathrm{Li}_{2} \mathrm{Mo}_{2} \mathrm{O}_{7}$. An $\mathrm{x}$-ray powder pattern of the 1:1 sample is described in Table III. No lines for $\mathrm{MoO}_{3}$ or $\mathrm{Li}_{2} \mathrm{MoO}_{4}$ were found in the diffraction pattern, thus precluding the possibility that the material is a mixture of $\mathrm{MOO}_{3}$ and $\mathrm{Li}_{2} \mathrm{MOO}_{4}$.

To determine whether the acid-base reaction occurs completely before the electrolysis experiments, the data of Table I were examined for a chemical reaction preceding charge transfer by plotting $I_{0} \tau^{1 / 2} / C$ vs. $I_{0}$ and $I_{0} / C$. The plots showed no discernible downward slope, but only a scatter that could be attributed to uncertainties in concentration owing to volatility of the oxychloride, and perhaps to variation in electrode area with the formation of solid deposit.

Plots of $E$ vs. $\log \left(\tau^{1 / 2}-t^{1 / 2}\right)$ were linear as shown in Fig. 3. This function would be expected to yield linear plots either for a totally irreversible charge transfer process or for a reversible process with the formation of a solid product of constant activity. Current reversal chronopotentiometry showed an anodic transition upon reversal of the current at the inflection point (Fig. 4): ratios of the coulombs of charge in the forward to backward electrolysis varied between 0.985 and 1.025 , indicating the quantitative formation of a solid product that can be reoxidized. If the slope of the $\log$ plot is equated to $2.3 R T / \alpha n_{\mathrm{a}} \mathrm{F}$, we calculate

Table II. Melting points of $\mathrm{MoO}_{3}-\mathrm{Li}_{2} \mathrm{MoO}_{4}$ system

\begin{tabular}{ccc}
\hline $\begin{array}{c}\text { Mole per } \\
\text { cent MoO, }\end{array}$ & $\begin{array}{c}\text { Móle per } \\
\text { cent LizMoO, }\end{array}$ & $\begin{array}{c}\text { Melting } \\
\text { point, }{ }^{\circ} \mathrm{C}\end{array}$ \\
\hline 42 & 58 & 550 \\
45 & 55 & 520 \\
48 & 52 & 595 \\
49 & 51 & 526 \\
50 & 50 & 534 \\
51 & 49 & 515 \\
53 & 47 & 535 \\
55 & 45 & 555
\end{tabular}

Table III. X-roy powder diffraction pattern of $\mathrm{Li}_{2} \mathrm{MO}_{2} \mathrm{O}_{7}$

\begin{tabular}{|c|c|}
\hline$d(A)$ & $I / I_{0}$ \\
\hline $\begin{array}{l}6.4241 \\
5.3679 \\
4.1385 \\
3.7824 \\
3.6820 \\
3.5199 \\
2.9809 \\
2.9780 \\
2.8823 \\
2.8331 \\
2.7136 \\
2.5074 \\
2.3659 \\
2.1917 \\
2.1396 \\
2.0064 \\
1.9012 \\
1.8398 \\
1.8294 \\
1.8030 \\
1.7697 \\
1.7323 \\
1.6937 \\
1.6161 \\
1.5900 \\
1.5522 \\
1.5043\end{array}$ & $\begin{array}{r}10 \\
10 \\
30 \\
10 \\
10 \\
80 \\
50 \\
50 \\
10 \\
10 \\
50 \\
10 \\
10 \\
100 \\
50 \\
60 \\
80 \\
5 \\
5 \\
5 \\
5 \\
5 \\
70 \\
10 \\
20 \\
90 \\
40\end{array}$ \\
\hline
\end{tabular}

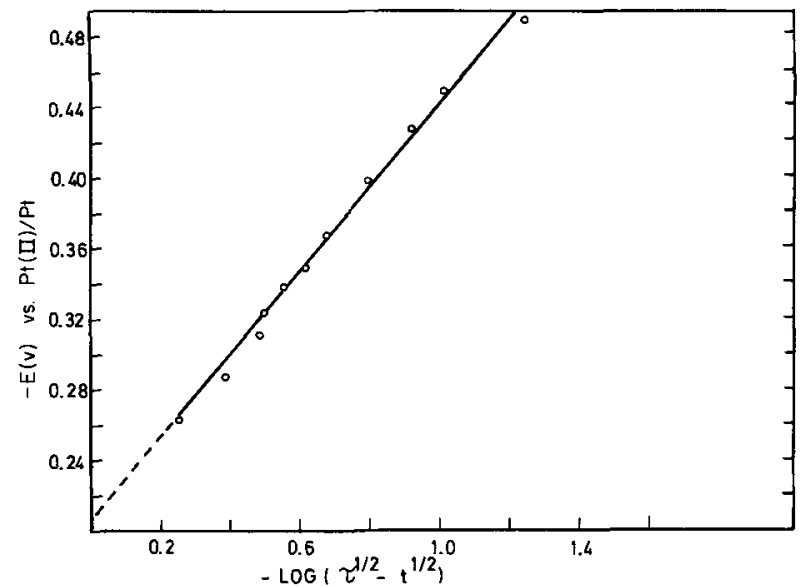

Fig. 3. Potential-time curve for the first reduction step of $\mathrm{MoO}_{3}$.

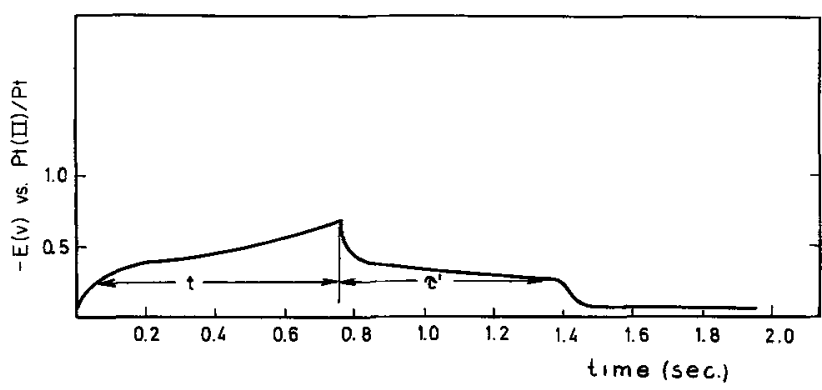

Fig. 4. Typical reverse current chronopotentiogram for the first reduction step of $\mathrm{MoO}_{3} . I_{\mathrm{f}}=I_{\mathrm{r}}=2.0 \mathrm{~mA} / \mathrm{cm}^{2}$.

$\alpha n_{\mathrm{a}}=0.56$ rather than 2 for a reversible process. Neglecting the back-reaction, the value of $k_{f, h}$ at $-0.208 \mathrm{~V}$, the starting potential, is calculated to be $3.18 \times 10^{-3} \mathrm{~cm}^{-\mathrm{sec}^{-1}}$.

Analysis of the reduction products of $\mathrm{MOO}_{3}$ - Samples of the first reduction product, prepared coulometrically from $0.35 \mathrm{M} \mathrm{MoO}_{3}$ solution using a platinum gauze cathode, in the form of a homogeneous, brownviolet solid, were boiled in distilled water to remove chlorides and soluble molybdates and dried at $130^{\circ}$. Analysis revealed only $\mathrm{MoO}_{2}$, and the $\mathrm{x}$-ray powder pattern agreed in d-spacings and approximate relative densities with the ASTM files for $\mathrm{MoO}_{2}$.

Attempts were also made to prepare the second reduction product, by holding the potential of the working electrode at $-1.75 \mathrm{~V}$. A product showing $\mathrm{x}$-ray lines of $\mathrm{MoO}_{2}$, plus several weak lines, and containing $\mathrm{Li}$ but not $K$ was formed, corresponding to a mixture of the first and second reduction products. The composition could not be completely accounted for in terms of $\mathrm{MoO}_{2}$ and $\mathrm{Li}_{2} \mathrm{O}$ or $\mathrm{MO}_{2} \mathrm{O}_{5}$ and $\mathrm{Li}_{2} \mathrm{O}$. It is possible that the second reduction product is partially soluble in the melt.

$\mathrm{MoO}_{2} \mathrm{Cl}_{2}-\mathrm{LiCl}-\mathrm{KCl}$-system.-The solubility of $\mathrm{MoO}_{2} \mathrm{Cl}_{2}$ in the melt was determined at three temperatures, $400^{\circ}, 450^{\circ}$, and $500^{\circ}$, by saturating an argon gas stream with the vapor and bubbling the dilute stream (heated to $120^{\circ}$ to avoid crystallization from the vapor) through the melt for at least $2 \mathrm{hr}$, and analyzing the melt for molybdenum. The solubility was found to be $2.60 \pm 0.12,2.75 \pm 0.14$, and $2.78 \pm 0.09 \times 10^{-5}$ moles $\mathrm{MoO}_{2} \mathrm{Cl}_{2} / \mathrm{cm}^{3}$ at the three temperatures. The relatively high solubility and low vapor pressure over the melt indicates a strong interaction between $\mathrm{MoO}_{2} \mathrm{Cl}_{2}$, probably to form an anion $\mathrm{MoO}_{2} \mathrm{Cl}_{4}=$ with the chloride ion of the melt.

Chronopotentiometry indicated a single wave, occurring at a potential of $-0.35 \mathrm{~V}$, in agreement with the postulated interaction between $\mathrm{MoO}_{3}$ and melt. From the value of $I_{0} \tau^{1 / 2} / C=560 \pm 10 \mathrm{~A}-\mathrm{sec}^{1 / 2} \mathrm{~cm}$ $\mathrm{mol}^{-1}, n=2$, the diffraction coefficient was calculated to be $1.08 \times 10^{-5} \mathrm{~cm}^{2} / \mathrm{sec}$. 
Table IV. Chronopotentiometric data for the first reduction step of $\mathrm{Li}_{2} \mathrm{Mo}_{2} \mathrm{O}_{7}$

\begin{tabular}{|c|c|c|c|}
\hline $\begin{array}{c}C_{\mathrm{KO}_{2} \mathrm{O}_{7}}= \\
\text { (millimolar) }\end{array}$ & $I_{0}(\mathrm{~mA})$ & $\begin{array}{c}I_{0} \tau^{1 / 2} \\
\left(\mathrm{~mA}-\mathrm{sec}^{1 / 2} / \mathrm{cm}^{2}\right)\end{array}$ & $\begin{array}{c}I_{0} \tau^{1 / 2} / C \\
\left(A-\sec ^{1 / 2} \mathrm{~cm}^{3} \text { mole }^{-1}\right)\end{array}$ \\
\hline 3.48 & $\begin{array}{l}1.60 \\
2.00 \\
2.44 \\
3.00\end{array}$ & $\begin{array}{l}1.92 \\
1.82 \\
1.81 \\
1.77\end{array}$ & $\begin{array}{r}\mathbf{5 5 2} \\
\mathbf{5 2 4} \\
\mathbf{5 2 0} \\
\mathbf{5 0 9} \\
\text { Avg } \mathbf{5 2 6}\end{array}$ \\
\hline 10.80 & $\begin{array}{l}6.00 \\
7.00 \\
7.50 \\
8.00\end{array}$ & $\begin{array}{l}4.97 \\
4.85 \\
4.77 \\
4.55\end{array}$ & $\begin{array}{r}460 \\
449 \\
442 \\
421 \\
\text { Avg } 443\end{array}$ \\
\hline 21.23 & $\begin{array}{r}6.00 \\
8.00 \\
8.00 \\
10.00\end{array}$ & $\begin{array}{l}8.15 \\
7.84 \\
7.74 \\
7.80\end{array}$ & $\begin{array}{r}383 \\
369 \\
364 \\
366 \\
y+371\end{array}$ \\
\hline 85.40 & $\begin{array}{l}28.00 \\
30.00 \\
34.00 \\
36.00\end{array}$ & $\begin{array}{l}33.05 \\
31.20 \\
31.28 \\
30.96\end{array}$ & $\begin{array}{r}348 \\
327 \\
331 \\
324 \\
\text { Avg } 332\end{array}$ \\
\hline
\end{tabular}

Constant current electrolysis carried out at potentials never more negative than $-0.35 \mathrm{~V}$, of a solution of $\mathrm{MoO}_{2} \mathrm{Cl}_{2}$ prepared by bubbling the vapor through the melt for $2 \mathrm{hr}$ produced a brown-violet deposit. Comparison of the micromoles of molybdenum with the microfaradays of current consumed indicated a consumption of two electrons per molybdenum atom. The $x$-ray powder pattern agreed with that of the first reduction product of $\mathrm{MoO}_{3}$ and with the ASTM pattern of $\mathrm{MoO}_{2}$. The electrode reaction at $-0.35 \mathrm{~V}$ can thus be described as

or

$$
\mathrm{MoO}_{2} \mathrm{Cl}_{2}+2 e^{-} \rightleftarrows \mathrm{MoO}_{2}+2 \mathrm{Cl}^{-}
$$

$$
\mathrm{MoO}_{2} \mathrm{Cl}_{4}=+2 e^{-} \rightleftarrows \mathrm{MoO}_{2}+4 \mathrm{Cl}-
$$

$\mathrm{Li}_{2} \mathrm{Mo}_{2} \mathrm{O}_{7}-\mathrm{LiCl}-\mathrm{KCl}$ system.-The chronopotentiometric behavior of $\mathrm{Li}_{2} \mathrm{Mo}_{2} \mathrm{O}_{7}$ was found to be quite similar to that of $\mathrm{MoO}_{3}$. Two waves were observed, one at $-0.44 \mathrm{~V}$ and the other at approximately $-1.75 \mathrm{~V}$. The transition time data for the first reduction process (Table IV) were somewhat scattered, showing a trend to decrease with concentration and with increasing current density. When both $\mathrm{MOO}_{3}(3.55 \mathrm{mM})$ and $\mathrm{Li}_{2} \mathrm{Mo}_{2} \mathrm{O}_{7}(2.15 \mathrm{mM})$ were present, two waves were once again observed, one at $-0.37 \mathrm{~V}$ and the other at $-1.75 \mathrm{~V}$. It is concluded that the first wave of $\mathrm{MOO}_{3}$ is actually the sum of the first waves of $\mathrm{MoO}_{2} \mathrm{Cl}_{2}$ and $\mathrm{Mo}_{2} \mathrm{O}_{7}=$.

The first reduction product of $\mathrm{Li}_{2} \mathrm{MO}_{2} \mathrm{O}_{7}$ was characterized as before, and identified as $\mathrm{MoO}_{2}$. Accordingly, the first reduction process can be written

$$
\mathrm{Mo}_{2} \mathrm{O}_{7}=+4 e^{-} \rightarrow 2 \mathrm{MoO}_{2}+3 \mathrm{O}=
$$

with a following acid-base reaction, no doubt

$$
3 \mathrm{Mo}_{2} \mathrm{O}_{7}=+3 \mathrm{O}=\rightarrow 6 \mathrm{MoO}_{4}=
$$

The complexity of this process presumably accounts for the lack of diffusion control in the over-all process.

$\mathrm{MoO}_{4}=-\mathrm{LiCl}-\mathrm{KCl}$ system.-Chronopotentiograms were recorded over a concentration range of $8.03 \times$ $10^{-3} \mathrm{M}$ to $0.2725 \mathrm{M} \mathrm{Li} 2 \mathrm{MoO}_{4}$. At current densities below $2 \mathrm{~mA} / \mathrm{cm}^{2}$, two waves were discerned, one at $-0.85 \mathrm{~V}$ and the other at $-1.75 \mathrm{~V}$. The first wave increased with concentration until the concentration reached $1.12 \times 10^{-2} \mathrm{M}$, and leveled off at higher concentrations (Fig. 5). The slope of the plot at low concentrations yielded $I_{0} \tau^{1 / 2} / \mathrm{C}=9.87 \pm 0.6 \mathrm{~A}-\mathrm{sec}^{1 / 2} \mathrm{~cm}$ $\mathrm{mol}^{-1}$ corresponding to $n D^{1 / 2}=1.45 \times 10^{-4} \mathrm{~cm}$ $\mathrm{sec}^{-1 / 2}$. Such an abnormally low transition time constant suggests an equilibrium such as

$$
\mathrm{MoO}_{4}=+2 \mathrm{Cl}-\rightleftarrows \mathrm{MoO}_{3} \mathrm{Cl}_{2}=+\mathrm{O}=
$$

in which $\mathrm{MoO}_{3} \mathrm{Cl}_{2}=$ exists as a minority component responsible for the first reduction step. If such an equilibrium exists, it must be relatively slow, because $I_{0} \tau^{1 / 2}$ was not found to decrease with increasing cur-

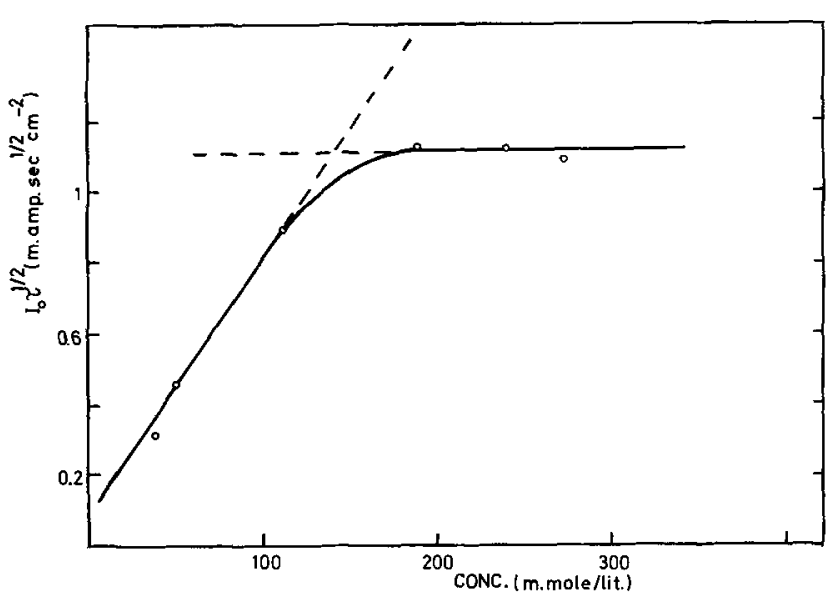

Fig. 5. Variation of $\mathrm{I}_{0} \tau^{1 / 2}$ with $\mathrm{Li}_{2} \mathrm{MoO}_{4}$ concentration for the first reduction step.

rent density as would be expected for a prior chemical step with appreciable interconversion during the time of electrolysis.

With a molybdate concentration of $5.35 \times 10^{-2} \mathrm{M}$ and with a current density of $16 \mathrm{~mA} / \mathrm{cm}^{2}$ only the second transition was observed. The Sand equation was tested for four to five current densities at five different molybdate concentrations (Table V). The average value of $I_{0} \tau^{1 / 2} / \mathrm{C}$ calculated from these data is $174 \pm 6 \mathrm{~A}-\mathrm{sec}^{1 / 2} \mathrm{~cm} \mathrm{~mol}-1$, corresponding to $D=$

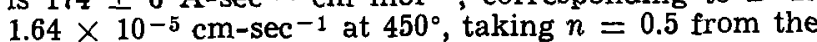
analytical data given below.

Attempts to prepare the first reduction product by constant current electrolysis were unsuccessful. Using $0.85 \mathrm{M} \mathrm{Li}_{2} \mathrm{MoO}_{4}$, even with current densities lower than $100 \mu \mathrm{A} / \mathrm{cm}^{2}$, the electrode potential rapidly rose beyond that corresponding to the first reduction step. Using current densities of $100 \mu \mathrm{A}, 5 \mathrm{~mA}$, and $10 \mathrm{~mA} /$ $\mathrm{cm}^{2}$, deposits were prepared by electrolyzing at -1.18 to $-1.2 \mathrm{~V}$, at $-1.5 \mathrm{~V}$, and at $-1.75 \mathrm{~V}$, respectively. Examination of the cathodes showed only one type of solid product, an adherent dark brown-black solid with a metallic luster. The samples were washed with distilled water, dried at $130^{\circ}$, and analyzed for $\mathrm{Li}$ and Mo with the results given in Table VI. The deposit was found to contain an average of $54.0 \% \mathrm{Mo}$ and $9.85 \% \mathrm{Li}$ but no $\mathrm{K}$ or $\mathrm{Cl}$. The ratio $\mathrm{Li} / \mathrm{Mo}$ is 2.52 . No appreciable trend of composition with current density was observed. If it is assumed that the deposit contains only $\mathrm{Li}, \mathrm{Mo}$, and $\mathrm{O}$, the empirical formula $\mathrm{Li}_{2.49}$ $\mathrm{MoO}_{3.96}$ is obtained indicating an average oxidation state of 5.5 for molybdenum.

Additional preparations produced at $-1.75 \mathrm{~V}$ were analyzed for oxidation state, with the results listed in Table VII. The sum of $\mathrm{Li}_{2} \mathrm{O}, \mathrm{Mo}_{2} \mathrm{O}_{5}$, and $\mathrm{MoO}_{3}$ is very close to $100 \%$, confirming the absence of $\mathrm{K}$ and $\mathrm{Cl}$, and indicating once more that the product is $\mathrm{Li}_{2.5} \mathrm{MoO}_{4}$ or $\mathrm{Li}_{5} \mathrm{MO}_{2} \mathrm{O}_{8}$. To ascertain whether the product is a single compound or a mixture, an x-ray powder pattern was obtained for the products prepared at $-1.2,-1.5$, and $-1.75 \mathrm{~V}$. The $\mathrm{d}$ spacing along with relative intensities are given in Table VIII. No lines for $\mathrm{LiCl}$ or $\mathrm{Li}_{2} \mathrm{MoO}_{4}$ were found in the diffraction pattern. The diffraction data do not correspond with any known molybdenum compound listed in the ASTM files or with other deposits obtained by reduction of $\mathrm{Mo}(\mathrm{VI})$ compounds.

Table V. Chronopotentiometric data for the second reduction step of lithium molybdate

\begin{tabular}{ccc}
$\begin{array}{c}\text { Molybdate conc. } \\
\text { (millimolar) }\end{array}$ & $\begin{array}{c}I_{0} \tau^{1 / 2} \\
\left(\mathrm{~mA}-\mathrm{sec}^{1 / 2} / \mathrm{cm}^{2}\right)\end{array}$ & $\begin{array}{c}\text { Range of } I_{0} \\
\left(\mathrm{~mA} / \mathrm{cm}^{2}\right)\end{array}$ \\
\hline 8.03 & $1.29 \pm 0.08$ & $2.5-4.0$ \\
20.80 & $3.46 \pm 0.06$ & $6.0-10.0$ \\
53.50 & $9.72 \pm 0.09$ & $24.0-20.0$ \\
110.02 & $20.04 \pm 0.18$ & $24.0-44.0$ \\
178.05 & $31.00 \pm 0.90$ & $26.0-34.0$
\end{tabular}


Table VI. Typical analysis of $\mathrm{Li}_{2} \mathrm{MoO}_{4}$ deposit prepared at constant current

\begin{tabular}{|c|c|c|c|c|c|c|}
\hline Sample & $\mathbf{A}$ & $\mathbf{B}$ & c & D & $\mathbf{E}$ & $\mathbf{F}$ \\
\hline $\begin{array}{l}\text { Current density, } \mathrm{mA} / \mathrm{cm}^{2} \\
\text { Sample weight, mg } \\
\text { Li, mg found } \\
\text { Per cent weight } \mathrm{Li} \\
\text { Mo, mg found } \\
\text { Per cent weight } \mathrm{Mo} \\
\text { Per cent weight } \mathrm{O}=\text { to } 100 \% \\
\text { Li found, } \mu \text { moles } \\
\text { Mo found, } \mu \text { moles } \\
\text { O calculated, } \mu \text { moles } \\
\text { Empirical formula }\end{array}$ & $\begin{array}{c}5 \\
73.5 \\
7.17 \\
9.7 \\
39.6 \\
53.9 \\
36.3 \\
1035 \\
412 \\
1670 \\
\mathrm{Li}_{2.51} \mathrm{MOO}_{3.25}\end{array}$ & $\begin{array}{l}5 \\
129.9 \\
12.7 \\
9.8 \\
70.6 \\
54.4 \\
35.8 \\
1830 \\
736 \\
2920 \\
\text { Li2.40MOOs.86 }\end{array}$ & $\begin{array}{l}5 \\
112.5 \\
11.0 \\
9.8 \\
61.1 \\
54.1 \\
36.1 \\
1585 \\
636 \\
2520 \\
\mathrm{Li}_{2.40 \mathrm{MOO}} \\
\end{array}$ & $\begin{array}{l}10 \\
150.6 \\
15.2 \\
10.1 \\
81.2 \\
53.8 \\
36.1 \\
2200 \\
846 \\
3380 \\
\mathrm{Li}_{2.59 \mathrm{MOO}_{3} .89}\end{array}$ & $\begin{array}{l}10 \\
148.2 \\
14.7 \\
9.9 \\
80.23 \\
54.0 \\
36.1 \\
2120 \\
835 \\
3320 \\
\mathrm{Li}_{2.55} \mathrm{MoO}_{3.86}\end{array}$ & $\begin{array}{l}10 \\
134.5 \\
13.2 \\
9.9 \\
72.2 \\
53.6 \\
36.5 \\
1910 \\
753 \\
3065 \\
\text { Li2.54MOO..07 }\end{array}$ \\
\hline
\end{tabular}

Table VII. Determination of the empirical formula of $\mathrm{Li}_{2} \mathrm{MoO}_{4}$ deposit prepared at constant potential

\begin{tabular}{|c|c|}
\hline Sample & A \\
\hline $\begin{array}{l}\text { Milliliters } 0.05 \mathrm{~N} \mathrm{Na} \mathrm{Na}_{2} \mathrm{O}_{8} \\
\text { Milligrams } \mathrm{NaIO} \text { calculated } \\
\text { Milligram total Mo calculated } \\
\text { Average valence of Mo } \\
\text { Micromoles } \mathrm{Lj} \\
\text { Milligrams } \mathrm{LigO} \\
\text { Total Mo, mg } \\
\text { Micromoles Mo } \\
\text { Milligrams Mo(V) } \\
\text { Milliggrams Moo } \\
\text { Milligrams Mo(vi) } \\
\text { Milligrams MoOs } \\
\text { Total mg found } \\
\text { Sample weight, mg } \\
\text { Per cent weight found } \\
\text { Empirical formula }\end{array}$ & $\begin{array}{c}6.29 \\
25.9 \\
50.7 \\
5.50 \\
1320 \\
19.8 \\
50.7 \\
528 \\
25.0 \\
35.6 \\
25.7 \\
38.4 \\
93.8 \\
92.6 \\
101.9 \\
\text { Li:.50M.1.00 }\end{array}$ \\
\hline \multicolumn{2}{|c|}{$\begin{array}{l}\text { To study the stability of the product, one sample } \\
\text { was heated at } 300^{\circ} \text { under vacuum. No change in dif- } \\
\text { fraction pattern was observed. The deposit was further } \\
\text { boiled in distilled water } 3 \mathrm{hr} \text { and dried at } 200^{\circ} \text {. The } \\
\text { boiled product exhibited a different } \mathrm{x}-\mathrm{ray} \text { pattern as } \\
\text { shown in Table IX. The analytical data indicated } \mathrm{Li} / \\
\mathrm{Mo} \text { to be } 4.43 / 2 \text { and the sum of the weight percent- } \\
\text { ages of } \mathrm{Li}_{2} \mathrm{O}+\mathrm{MoO} \text { to be } 97.66 \text {, indicating the pres- } \\
\text { ence of water in the sample or partial oxidation of } \\
\mathrm{Mo}_{2} \mathrm{O}_{5} \text {. }\end{array}$} \\
\hline
\end{tabular}

The electrode reaction of molybdate can be written

$$
2 \mathrm{MoO}_{4}=+e^{-} \rightarrow \mathrm{MO}_{2} \mathrm{O}_{8}^{-5}
$$

The mechanism of this reaction is unclear. There is no evidence for dimerization of molybdate prior to reduction, and the diffusion coefficient is consistent

Table VIII. X-ray powder diffraction pottern of $\mathrm{Li}_{5} \mathrm{M}_{2} \mathrm{O}_{8}$

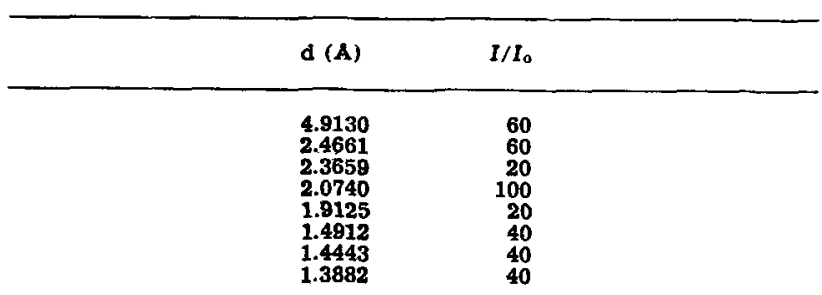

Table IX. X-ray powder diffraction pattern of boiled deposit

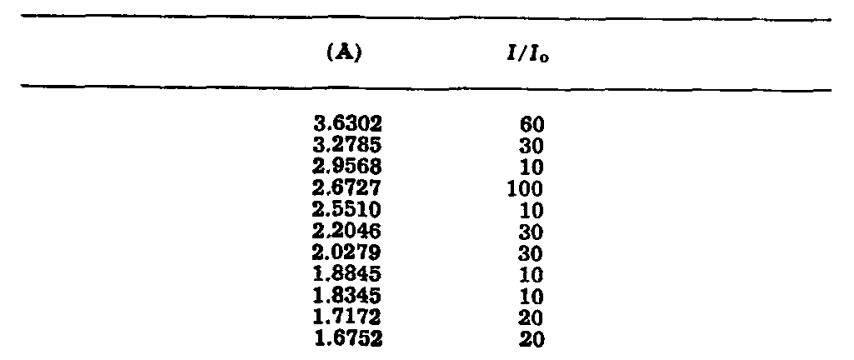

B

$\mathbf{C}$

7.42
29.8
60.7
5.51
1600
23.8
60.7
632
29.8
42.2
31.0
46.2
112.3
113.5
99.2
Li2.62MoO

with our expectation for a monomer. The simplest mechanism would be the formation of the anion $\mathrm{MoO}_{4}{ }^{3-}$, with the incorporation of equimolar amounts of $\mathrm{MoO}_{4}^{2-}$ with lithium ions to form the crystalline compound $\mathrm{Li}_{5} \mathrm{Mo}_{2} \mathrm{O}_{8}$.

\section{Acknowledgment}

One of the authors (B. N. P.) is indebted to the University of Illinois for the support in the form of research assistantship. Financial support of this research was provided by the United States Army Research Office-Durham and by the Center for Application of Radioisotopes in Industry, Skopje, Yugoslavia.

Manuscript submitted March 30, 1973; revised manuscript received May 18, 1973

Any discussion of this paper will appear in a Discussion Section to be published in the June 1974 JourNaL.

\section{REFERENCES}

1. A. Stavenhagen and E. Engels, Ber., 28, 2281 (1895).

2. C. Cannery, Gazz. Chim. Ital., 60, 113 (1930).

3. W. G. Burgers and J. A. M. Van Liempt, Z. Anorg. Allgem. Chem., 302, 325 (1931).

4. A. Magnéli, N. Acta Reg., Sc. Upsaliensis, 14, No. 816 (1939).

5. G. Hagg, $Z$. Physik. Chem., B29, 192 (1935).

6. A. Wold, W. Kunnmann, R. J. Arnott, and A. Ferretti, Inorganic Chem., 3, 545 (1964).

7. S. Senderoff and A. Brenner, This Journal, 101, 16 (1954).

8. S. Senderoff and A. Brenner, ibid., 101, 31 (1954).

9. H. A. Laitinen and J. H. Propp, Anal. Chem., 38, 644 (1969).

10. H. A. Laitinen and B. N. Popov, This Journal, 117, $482(1970)$.

11. H. A. Laitinen and K. W. Hanck, ibid., 118, 1123 (1971).

12. H. A. Laitinen and K. R. Lucas, ibid., 12, 553 (1966).

13. H. A. Laitinen and D. R. Rhodes, ibid., 10, 413 (1962).

14. G. H. Aylward, Anal. Chim. Acta, 14, 386 (1956).

15. P. Bourret, J. M. Lecure, and K. Weis, Chim. Anal. (Paris), 52, (1) 48 (1970). 